\title{
Consumption, nutrient digestibility and lactation performance of dairy cows fed soybeans in different forms
}

\section{Consumo, digestibilidade de nutrientes e desempenho lactacional de vacas leiteiras alimentadas com soja de diferentes formas}

\author{
Angela Maria de Vasconcelos ${ }^{1 *}$; Sebastião de Campos Valadares Filho; \\ Marcia Dias ${ }^{3}$; Vinicio Araujo Nascimento ${ }^{3}$; Débora Andréa Evangelista Façanha ${ }^{4}$; \\ Juliano José de Resende Fernandes ${ }^{5}$
}

\begin{abstract}
Twelve Holstein cows were given diets containing soybean supplied in different ways in order to identify possible changes in lactation performance and evaluate the economic feasibility of the diets. The diets included: soybean meal only (SM-control); raw soybean (RaS); roasted soybean (RoS) and soybean meal plus $5 \%$ urea (SMU). The forage consisted of corn silage. We analyzed the dry matter intake, milk production and collected milk samples. To estimate digestibility, we collected six samples of feces over a period of six consecutive days. The intake of dry matter (DM), organic matter (OM), neutral detergent fiber (NDF) and non-fiber carbohydrates (NFC) did not differ among treatments. On the other hand, crude protein (CP) intake was influenced by the diets, and the highest mean values of ether extract (EE) were found with the RaS and RoS diets. The intake of total digestible nutrients (TDN) was lower in the RaS and RoS diets compared to the control diet. DM, OM, CP, EE, and NDF digestibility were not affected by the different diets, while NFCs were reduced in the RoS diet and TDN decreased with both the RaS and RoS diets. There were also no differences observed across diets for total milk production, production corrected to $3.5 \%$ fat, diet efficiency, or milk per kilogram of dry matter and/or crude protein. We conclude that raw and roasted soybeans as well as concentrate plus $5 \%$ urea in dry matter may be used instead of soybean meal as feed for high-producing cows, without affecting milk production and composition. We also observed that the SMU diet was the least costly.

Key words: Milk constituents, processing methods, metabolizable protein, economic viability
\end{abstract}

\section{Resumo}

Utilizou-se 12 animais da raça Holandesa para avaliar o efeito de dietas contendo soja fornecida de diferentes formas e obter informações sobre possíveis alterações no desempenho lactacional como também verificar sua viabilidade econômica. As dietas constituíam-se de farelo de soja exclusivo (FS-

\footnotetext{
${ }^{1}$ Zootenista, Prof ${ }^{\mathrm{a}} \mathrm{Dr}^{\mathrm{a}}$, Universidade Estadual Vale do Acaraú, UVA, Centro de Ciências Agrárias e Biológicas, CCAB, Curso de Zootecnia, Sobral, CE, Brasil. E-mail: angv06@hotmail.com

2 Zootecnista, Prof. Dr., Universidade Federal de Viçosa, UFV, Centro de Ciências Agrárias, Dept ${ }^{\circ}$ de Zootecnia, Viçosa, MG, Brasil. E-mail: scvfilho@ufv.br

3 Veterinários, Profs. Drs., Universidade Federal de Goiás, UFG, Curso de Zootecnia, Campus Jataí, Jataí, GO, Brasil. E-mail: diasmarcia@yahoo.com.br; vinicioaraujon@yahoo.com

${ }^{4}$ Eng $^{\text {a }}$ Agr $^{\mathrm{a}}$, Prof ${ }^{\mathrm{a}}$ Dr $^{\mathrm{a}}$, Dept ${ }^{\mathrm{o}}$ de Ciências Animais, Mossoró, Universidade Federal do Semi Árido, UFERSA, RN, Brasil. E-mail: debora_ufersa@hotmail.com

5 Veterinário, Prof. Dr., UFG, Escola de Veterinária e Zootecnia, Campus Samambaia, Goiânia, GO, Brasil. E-mail: julianojrf@ gmail.com

* Author for correspondence
} 
controle); soja crua (SC); soja tostada (ST) e farelo de soja mais 5\% de uréia (FSU). O volumoso foi à silagem de milho. Foram registrados consumo de matéria seca, produção de leite e colhidas amostras de leite. Para estimativa da digestibilidade foram coletadas seis amostras de fezes durante seis dias consecutivos. Os consumos de matéria seca (MS), matéria orgânica (MO), fibra detergente neutra (FDN) e carboidratos não fibrosos (CNF) não diferiram. O consumo de proteína bruta (PB) foi influenciado pelas dietas e as maiores médias de extrato etéreo (EE) foram com a SC e ST. O consumo dos nutrientes digestíveis totais (NDT) foi menor com a inclusão da SC e ST em relação à dieta controle. A digestibilidade da MS, MO, PB, EE, FDN não foram afetados e o CNF foi reduzido com ST e do NDT diminuiu com SC e ST. A produção total de leite e corrigida para 3,5\% de gordura, sua eficiência e leite por quilograma de matéria seca e/ou proteína bruta não diferiram. Os grãos de soja crus e tostados como também concentrado adicionado de $5 \%$ de ureia na matéria seca podem ser usados como alternativas na alimentação de vacas de alta produção em substituição ao farelo de soja sem prejuízo para a produção e composição do leite. A dieta com FSU teve menor custo.

Palavras-chave: Constituintes lácteos, métodos de processamentos, proteína metabolizável, viabilidade econômica

\section{Introduction}

Milk production systems in Brazil are quite diverse, and the inadequate management of food, health and reproduction, as well as the low genetic potential of cattle contribute to a low average productivity (about 1260 liters/cow/year, corresponding to approximately 4.70 liters/cow/day) (IBGE, 2012).

Dairy farmers have been seeking alternative diets for high-producing dairy cows in an attempt to maximize energy consumption and metabolizable protein without affecting animal metabolism or performance. Such diets would also reduce production costs and increase profitability.

Among protein plant foods used as an alternative source of protein and energy, soy is considered one of the richest and most available oil seeds worldwide. In Brazil, the grain production for the 2013/2014 crop was estimated to be between 192,424 million and 196,650 million tons (CONAB, 2013).

Manipulating the diet with protein supplements containing soybean meal, crude and/or roasted soybean grain, and urea (a ruminally nondegradable protein), are potential alternatives for increasing the amount of metabolizable protein and improving production efficiency. Adding raw and roasted soybeans to the diet can contribute to better milk production and alter certain highly valued milk constituents, such as protein and fat.
Several studies have investigated the use of soybeans and the different methods of processing them. Quality management is critical for animal performance. There is controversy in the literature regarding the benefits of different processing methods. Therefore, more studies are needed to assess these methods and better guide producers in their work.

In a study in which ground soybean and soybean oil were added to the diet of lactating cows, Santos et al. (2001) concluded that adding various sources of lipids did not decrease production or alter the physicochemical composition of milk. Similarly, Andrade (2011) included soybean processed in different ways in the diet of dairy cattle and noted that there were no alterations in nutrient consumption or digestibility or in the physico-chemical composition of milk.

The aim of this study was to evaluate the effect of diets containing soybean processed in different ways, identify possible changes in lactation performance, and evaluate the economic viability of these different diets.

\section{Material and Methods}

This research study was conducted at the Unidade de Ensino, Pesquisa e Extensão em Gado de Leite (UEPE-GL; the dairy cattle education, research and extension unit) of the Department of 
Animal Science of the Federal University of Viçosa (UFV), Viçosa, Minas Gerais, Brazil.

We used 12 Holstein cows kept in the free stall housing system which were grouped according to initial milk production (30 kg/day), had an average of 160 days of lactation, a body condition score of 3.5 and 4th lactation order, and an approximate weight of $570 \mathrm{~kg}$. To group animals, we used a $4 \mathrm{x}$ 4 Latin square, and each section was assigned four animals that were subjected to four treatments in four distinct periods. Diets contained soybean meal (SM) only, raw soybeans (RaS), roasted soybeans
(RoS), or soybean meal plus 5\% urea (SMU). Because it provides a large supply of digestible protein, we heated soybeans to $145^{\circ} \mathrm{C}$ for 1 minute with steeping. We used corn silage as forage for all diets, which were formulated to be isoproteic, with $25 \%$ crude protein $(\mathrm{CP})$ in natural matter and approximately $16.5 \%$ crude protein in dry matter (Table 1). In all concentrates, sodium bicarbonate and magnesium oxide were mixed at a ratio of $2: 1$. Table 1 lists the proportions of ingredients in each concentrate, Table 2 lists the chemical composition of the concentrates and corn silage, and Table 3 lists the chemical composition of the experimental diets.

Table 1. Experimental diet ingredients and their proportions.

\begin{tabular}{lcccc}
\hline \multirow{2}{*}{ Ingredients $^{2}$} & \multicolumn{4}{c}{ Concentrates $^{1}$} \\
\cline { 2 - 5 } & SM & RaS & RoS & SMU \\
\hline Soybean meal & 41.01 & 9.62 & 0.974 & 9.68 \\
Corn meal & 55.53 & 41.00 & 47.93 & 81.84 \\
Raw soybeans & - & 46.02 & - & - \\
Roasted soybeans & - & - & 47.65 & - \\
Urea & - & - & - & 5.08 \\
Baking soda & 0.710 & 0.710 & 0.710 & 0.710 \\
Magnesium Oxide & 0.355 & 0.355 & 0.355 & 0.355 \\
Mineral mixture $^{2}$ & 2.40 & 2.40 & 2.40 & 2.40 \\
\hline
\end{tabular}

${ }^{1} \mathrm{SM}$ (soybean meal); RaS (raw soybean); RoS (roasted soybean); SMU (soybean meal plus 5\% urea). ${ }^{2}$ Mineral mixture $=$ Limestone (1.07\%); dicalcium phosphate (0.45\%); sodium chloride (7.8\%); K iodate (0.0227\%); Na selenite $(0.0106 \%)$; Cu sulfate $(0.5783 \%)$; zinc sulfate (1.1021\%); sulfur flower (11.37\%); Buffering 2:1 (sodium bicarbonate:magnesium oxide).

Table 2. Chemical composition of concentrates and corn silage used in the experimental diets as a percentage of DM.

\begin{tabular}{lccccc}
\hline \multirow{2}{*}{ Sample $^{1}$} & \multicolumn{5}{c}{ Concentrates } \\
\cline { 2 - 5 } \multicolumn{1}{c}{ SM } & RaS & RoS & SMU & Corn silage \\
\hline SM & 84.13 & 85.21 & 85.40 & 84.47 & 28.41 \\
RaS & 93.06 & 92.37 & 93.03 & 95.09 & 94.97 \\
RoS & 26.48 & 27.54 & 25.02 & 26.71 & 5.99 \\
ADIN & 5.23 & 4.65 & 5.02 & 4.73 & 2.32 \\
EE & 2.89 & 11.02 & 9.98 & 2.94 & 2.46 \\
FDN & 23.09 & 23.51 & 24.47 & 29.73 & 57.86 \\
FDNcp & 18.07 & 19.54 & 18.64 & 26.19 & 50.48 \\
CNF & 45.62 & 34.27 & 39.39 & 46.42 & 36.06 \\
L & 1.00 & 4.40 & 3.47 & 1.46 & 2.70 \\
\hline
\end{tabular}

${ }^{1} \mathrm{SM}$ (soybean meal); RaS (raw soybean); RoS (roasted soybean); SMU (soybean meal plus 5\% urea). ${ }^{2} \mathrm{DM}$ (dry matter); OM (organic matter), CP (crude protein); ADIN (acid detergent insoluble nitrogen); EE (ether extract); NDF (neutral detergent fiber); NDFap (neutral detergent fiber corrected for protein and ash); non-fiber carbohydrates (NFC) $=100-(\% \mathrm{NDFap}+\% \mathrm{CP}+\% \mathrm{EE}+\%$ ash $)$; L (lignin). 
The experimental period lasted 84 days. The first 14 days of each period were used for animals' adaptation to the experimental diets and data collection was performed during the following seven days. All cows were weighed at the beginning and end of each period after the morning milking on an empty stomach.

Table 3. Chemical composition of the experimental diets as a percentage of DM.

\begin{tabular}{lcccc}
\hline & \multicolumn{3}{c}{ Diets $^{1}$} \\
\cline { 2 - 5 } Sample $^{2}$ & SM & RaS & RoS & SMU \\
\hline DM & 56.20 & 56.80 & 56.90 & 56.43 \\
OM & 94.01 & 93.66 & 93.99 & 95.02 \\
CP & 16.23 & 16.76 & 15.50 & 16.32 \\
ADIN & 3.77 & 3.48 & 3.67 & 3.05 \\
EE & 2.54 & 6.74 & 6.22 & 2.70 \\
RDP $^{3}(\% \mathrm{CP})$ & 63.50 & 65.48 & 53.37 & 76.67 \\
$\mathrm{RNDP}^{3}(\% \mathrm{CP})$ & 36.50 & 34.52 & 46.63 & 23.33 \\
NDF & 40.47 & 40.68 & 41.16 & 43.79 \\
NDFap & 34.27 & 34.25 & 34.56 & 38.33 \\
$\mathrm{CNF}$ & 40.74 & 35.36 & 37.72 & 41.24 \\
$\mathrm{~L}$ & 1.40 & 3.55 & 3.08 & 2.08 \\
\hline
\end{tabular}

${ }^{1} \mathrm{SM}$ (soybean meal); RaS (raw soybean); RoS (roasted soybean); SMU (soybean meal plus 5\% urea). ${ }^{2} \mathrm{DM}$ (dry matter); OM (organic matter), CP (crude protein); ADIN (acid detergent insoluble nitrogen); EE (ether extract); ${ }^{3}$ ruminally degradable protein (RDP), ruminally non-degradable protein (RNDP) estimated with the National Research Council equation, (2001); NDF (neutral detergent fiber); NDFap (neutral detergent fiber corrected for protein and ash); non-fiber carbohydrates $(\mathrm{NFC})=100-(\% \mathrm{NDFap}$ $+\% \mathrm{CP}+\% \mathrm{EE}+\%$ ash); L (lignin).

Animals were housed in individual pens with rubber flooring that contained troughs and automatic drinking fountains. The diet consisted of $70 \%$ complete mixture (concentrate) and 30\% forage, offered twice daily and ad libitum following the morning (8:00) and afternoon (16:00) milkings, which produced 5 to $10 \%$ natural matter leftovers. The forage plus concentrate feed provided to each animal was weighed and recorded daily, and the leftovers were weighed and discarded before the morning feeding to allow for any necessary adjustments in the quantity offered. The forage was sampled weekly, the leftovers daily, and the concentrate at every new mixture. All were stored at $4{ }^{\circ} \mathrm{C}$ and at the end of each period, a sample was created containing the leftovers, forage and concentrate for each cow. Chemical analyses were conducted as described by Silva and Queiroz (2002).
From the $15^{\text {th }}$ to the $21^{\text {st }}$ day of each experimental period, we used the mechanical milking scale to monitor and record daily milk production/cow milking (in $\mathrm{kg}$ ) in the morning and afternoon. Milk production was corrected to $3.5 \%$ fat using the following formula: MFP (milk fat percentage) = $(0.432+0.1625 * \mathrm{~F}) * \mathrm{~kg}$ of milk, where $\mathrm{F}=\%$ milk fat (SKLAN et al., 1992).

Individual milk samples were collected with the automatic milking system on the $17^{\text {th }}$ and $19^{\text {th }}$ days during the morning and afternoon milkings and a representative composite sample from both collections was created, as recommended by Broderick and Clayton (1997). The samples were

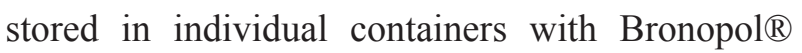
preservative (2-bromo-2-nitropropane-1.3-diol) and sent to the Laboratório de Qualidade do Leite (milk quality laboratory) of the Empresa Brasileira de Pesquisa Agropecuária (EMBRAPA; Brazilian 
Agricultural Research Corporation, Dairy Cattle), where levels of crude protein, lactose and fat were determined using Bentley Comb 2003 equipment.

To estimate the apparent digestibility of dry matter and nutrients, we collected six samples of feces during a period of six consecutive days, starting on the 16th day of each period and with an interval of 26 hours between sample collections. The first sample was collected at 8:00 on the first day and the last at 18:00 on the $21^{\text {st }}$ day, as described by Itavo et al. (2002). At the end of each period, after homogenization, the samples were frozen at $-20{ }^{\circ} \mathrm{C}$ for later analysis. They were pre-dried separately in a forced ventilation oven at $60{ }^{\circ} \mathrm{C}$ for 72 hours and ground in 2-mm sieves. We then elaborated a composite sample based on the pre-dry weight per cow for each period. Approximately five grams of fresh matter were weighed in $10 \mathrm{~cm}$ wide by 20 $\mathrm{cm}$ long nylon bags with an average porosity of 60 micrometers $\left(25 \mathrm{mg} / \mathrm{cm}^{2}\right)$, with ten replicates per treatment. The samples were then incubated in the rumen of a Holstein cow that had a rumen cannula and was fed a diet of 70:30 (concentrate:forage). After incubation, the bags were removed from the rumen and placed in ice water for 30 minutes to reduce microbial activity, then manually rinsed in tap water and dried in an oven at $65^{\circ} \mathrm{C}$ for 72 hours. We conducted laboratory analyses of dry matter (DM), ethereal extract (EE), mineral matter $(\mathrm{MM})$ and neutral detergent fiber free of ash and protein (NDFap), as described by Silva and Queiroz (2002). To determine the apparent digestibility, we used insoluble fiber in indigestible neutral detergent (NDFi) as an internal marker, which was obtained 264 hours after in situ incubation of the supplied feed, orts and feces, using Ankon ${ }^{\circledR}$ bags (filter bag F57), as described by Casali et al. (2008).

We also analyzed the feed costs (according to the methodology described by LOPES et al., 2003) to verify whether substituting soybean meal (the most commonly used ingredient in the diets of lactating cows) with raw soybeans, roasted soybeans or soybean meal with urea would produce any negative economic effects on the net milk sales revenue.

Data were subjected to analysis of variance using the SAS software, version 1999, and significance was set at $5 \%$. Means were compared with Tukey tests.

\section{Results and Discussion}

Diets did not differ in terms of DM, OM or NDF intake $(\mathrm{P}>0.05)$, but did in terms of $\mathrm{CP}, \mathrm{EE}$ and TDN $(\mathrm{P}<0.05)$ (Table 4).

Table 4. Average daily intake of dry matter (DDMI), organic matter (DOMI), crude protein (DCPI), ether extract (DEEI), neutral detergent fiber (DNDFI), non-fiber carbohydrates (NFC), TDN (total digestible nutrients) and variations in live animal weight as a result of the experimental diets, with the respective coefficients of variation (CV\%).

\begin{tabular}{|c|c|c|c|c|c|}
\hline \multirow{3}{*}{ Variables $^{2}$} & & & & & \multirow{3}{*}{ CV (\%) } \\
\hline & \multicolumn{4}{|c|}{ Diets $^{1}$} & \\
\hline & SM & $\mathrm{RaS}$ & RoS & SMU & \\
\hline & \multicolumn{4}{|c|}{ Intake (kg/day) } & \\
\hline DDMI & 19.71 & 18.99 & 19.06 & 19.63 & 3.86 \\
\hline DOMI & 18.40 & 17.78 & 17.82 & 18.31 & 4.02 \\
\hline DCPI & $3.43 \mathrm{a}$ & $3.18 b$ & $3.26 \mathrm{ab}$ & $3.37 \mathrm{a}$ & 4.51 \\
\hline DEEI & $0.58 \mathrm{~b}$ & $1.38 \mathrm{a}$ & $1.36 \mathrm{a}$ & $0.59 b$ & 7.41 \\
\hline DNDFI & 7.95 & 7.51 & 7.69 & 8.36 & 10.51 \\
\hline DNFCI & 8.48 & 8.05 & 8.19 & 8.38 & 5.12 \\
\hline TDN & $14.13 \mathrm{a}$ & $13.13 b$ & $12.76 \mathrm{~b}$ & $14.10 \mathrm{a}$ & 3.53 \\
\hline
\end{tabular}


Continuação

\begin{tabular}{|c|c|c|c|c|c|}
\hline \multirow[b]{2}{*}{ DM } & \multicolumn{4}{|c|}{ Intake (\%LV) } & \multirow[b]{2}{*}{3.66} \\
\hline & 3.40 & 3.27 & 3.28 & 3.39 & \\
\hline \multirow[t]{3}{*}{ NDF } & 1.37 & 1.27 & 1.33 & 1.41 & 9.45 \\
\hline & \multicolumn{4}{|c|}{ PV variation (g/day) } & \\
\hline & 0.580 & 0.577 & 0.591 & 0.580 & 146.21 \\
\hline
\end{tabular}

${ }^{1} \mathrm{SM}$ (soybean meal); RaS (raw soybean); RoS (roasted soybean); SMU (soybean meal plus 5\% urea); dry matter (DM); neutral detergent fiber (NDF). Means followed by different letters in the same row are significantly different (Tukey-Kramer test, 5\% probability); LV (live weight).

Dry matter intake was $19.35 \mathrm{~kg}$, which was equivalent to $3.33 \%$ of the live animal weight. These values were similar to those reported by Pina et al. (2006), which were 18.96 and $18.57 \mathrm{~kg}$ /day for the control and SMU diets, respectively. We observed lower consumption in diets containing raw and roasted soybeans (18.99 and $19.06 \mathrm{~kg} /$ day, respectively), which is probably due to the high lipid content found in raw grains and the lower proportion in roasted grains. This difference may also be attributed to the palatability of the diets and animals' selectivity, since we observed a certain rejection of the treatments during the experiment, especially to the raw soybean diet. Similar results were reported by Carvalho (2001) (19.07 kg/day, raw soy; $17.92 \mathrm{~kg} /$ day, roasted soy) and Barletta et al. (2012) (16.86, raw soy; $19.33 \mathrm{~kg} /$ day, roasted soy). Barnabé et al. (2007) evaluated the combination of energy and protein sources with different degrees of ruminal degradability in cows at 130 days of lactation and found that coarsely ground corn and roasted soybean yielded the highest intake $(24.50$ $\mathrm{kg}$ ). The DM intake in this study ranged from 18.99 to $19.71 \mathrm{~kg} /$ day, similar to the National Research Council recommendations (2001) of 18.2 to 19.8 $\mathrm{kg} /$ day for dairy cows producing 30 liters of milk/ day, adjusted for $3.5 \%$ fat, with an approximate live weight of $576 \mathrm{~kg}$.

There were significant differences $(\mathrm{P}<0.05)$ in $\mathrm{CP}$ intake among the four protein sources, with lower intake for the raw soybean diet $(3.18 \mathrm{~kg}$ /day) relative to the soybean meal (control) $(3.43 \mathrm{~kg} /$ day) and soybean meal with urea $(3.37 \mathrm{~kg} /$ day $)$ diets.
This may be due to the relatively lower DM intake in the control diet, since the diets were isoproteic. Therefore, the average CP intake for the soybean meal, raw soybean and roasted soybean diets was $3.29 \mathrm{~kg} /$ day. This is similar to that reported by Carvalho (2001): $3.35 \mathrm{~kg} /$ day for dairy cows fed diets that were $17.4 \% \mathrm{CP}$ of the total DM content. The CP intake of the soybean meal plus urea diet was higher $(3.37 \mathrm{~kg} /$ day $)$ than that reported by Pina et al. (2006), who recorded $2.92 \mathrm{~kg} /$ day in the diet of lactating dairy cows with $15.5 \% \mathrm{CP}$ in the total DM. It was also similar to that reported by Andrade (2011), who studied crossbred cows kept on pasture and supplemented with sugar cane and concentrate containing between 1.21 and $1.29 \mathrm{~kg}$ /day of raw and roasted soybean.

There was a difference in EE intake $(\mathrm{P}<0.05)$ among diets. Treatments containing raw soybean $(1.38 \mathrm{~kg} /$ day $)$ and roasted soybean $(1.36 \mathrm{~kg} /$ day $)$ had the highest EE values compared to diets containing soybean meal and soybean meal with urea, which can be explained by the high content of EE in soy grains (Table 4).

The NDF values, which were between 40.47 and $43.79 \%$ (Table 3), and the intake of $7.87 \mathrm{~kg}$ /day (1.34\% relative to live weight), were above those found by Andrade (2011) (i.e., 19.71 at 36.69\% and 4.71 at $5.40 \%$ ). Other authors reported means between 1.3 and 1.6 live weight for NDF intake (MOREIRA et al., 2001; OLIVEIRA et al., 2004).

The NFC intake (in kg/day) was not affected (P $>0.05)$ by the different diets and varied between 
35.36 and $41.24 \%$, remaining close to the range recommended by the NRC (2001) of 35 to $45 \%$ to prevent metabolic disorders such as ruminal acidosis. The TDN intake was lower $(\mathrm{P}<0.05)$ for diets containing soybeans $(13.13 \mathrm{~kg} /$ day for raw soybeans and $12.76 \mathrm{~kg} /$ day for roasted soybeans), relative to the control $(14.13 \mathrm{~kg} /$ day $)$ and soybean meal with urea $(14.10 \mathrm{~kg} /$ day $)$ diets.

DM digestibility was $67.19 \%$, on average, and did not differ $(\mathrm{P}>0.05)$ among diets. The digestibility coefficients of OM, CP, EE and NDF were also not affected $(\mathrm{P}>0.05)$ by the protein source (Table 5).

Table 5. Apparent digestibility of dry matter (ADDM), organic matter (ADOM), crude protein (ADCP), ether extract (ADEE), neutral detergent fiber (ADNDF), non-fibrous carbohydrates (ADNFC) and total digestible nutrient content (TDN), as well as the respective coefficients of variation obtained for the experimental diets.

\begin{tabular}{|c|c|c|c|c|c|}
\hline \multirow{2}{*}{ Item } & \multicolumn{4}{|c|}{ Diets $^{1}$} & \multirow{2}{*}{$\mathrm{CV}(\%)$} \\
\hline & SM & $\operatorname{RaS}$ & RoS & SMU & \\
\hline ADDM & 68.10 & 68.54 & 65.12 & 66.99 & 5.70 \\
\hline $\mathrm{ADOM}$ & 72.93 & 73.19 & 69.65 & 71.77 & 5.83 \\
\hline $\mathrm{ADCP}$ & 71.37 & 72.30 & 69.49 & 71.46 & 5.30 \\
\hline ADEE & 84.03 & 86.93 & 86.44 & 83.32 & 6.22 \\
\hline ADNDF & 52.48 & 55.20 & 52.40 & 53.54 & 11.03 \\
\hline ADNFC & $89.76 a$ & $87.88 \mathrm{ab}$ & $84.65 b$ & $89.67 \mathrm{a}$ & 3.34 \\
\hline TDN (\%DM) & $72.62 \mathrm{a}$ & $69.21 \mathrm{~b}$ & $67.00 \mathrm{~b}$ & $72.00 \mathrm{a}$ & 3.07 \\
\hline
\end{tabular}

${ }^{1} \mathrm{SM}$ (soybean meal); RaS (raw soybean); RoS (roasted soybean); SMU (soybean meal plus 5\% urea); dry matter (DM). Means for the same variable followed by the same letter in the same row do not differ (Tukey-Kramer test, $5 \%$ probability).

The digestibility of NFCs was lower $(\mathrm{P}<$ $0.05)$ for the roasted soybean diet compared to the control (soybean meal) and soybean meal plus urea diets, and this last diet did not differ from the raw soybean diet. The lower NFC in the raw and roasted soybean diets may be due to the longer time needed to reduce the soybean seed particles. This can affect microorganism action by reducing NFC digestibility, thus affecting the timing between sources of energy and protein (see Andrade (2001) for similar findings). The lack of reduced apparent digestibility of the organic matter suggests an unaltered ruminal environment, which is ideal for the development of microorganisms. According to Enjalbert et al. (1994), regardless of the form of lipid supplementation, fatty acids do not seem to affect the apparent digestibility of crude protein.

The TDN levels obtained in this study for the raw $(69.21 \%)$ and roasted soybean $(67.00 \%)$ diets were lower $(\mathrm{P}<0.05)$ compared to those in the soybean meal and soybean meal plus urea diets. Table 4 shows an average intake of $13.53 \mathrm{~kg}$, which is above the NRC recommendations (2001) (i.e., approximately $11.71 \mathrm{~kg}$ of TDN for the amount of milk production observed in this study). This difference may be associated with the lower values of DM intake observed in these treatments, due to the fact that the diets were rich in lipids, which lowers consumption due to the slow ruminal release and rate of passage through the digestive tract.

There were no differences $(\mathrm{P}>0.05)$ for any of the lactation performance variables (Table 6) across the studied diets.

The total milk production (TMP) also did not differ among the different diets. However, the $\mathrm{P}$ $>\mathrm{F}$ probabilities were very close to the minimum level. Perhaps the adjustment period for the diets 
(14 days), the duration of the experiment and the average lactation stage (160 days) did not allow for better milk production, especially in the raw and roasted soybean diets. We believe these factors may have reduced the apparent differences among diets.
Mourthé (2011) also did not observe an increase in milk production when assessing the effect of replacing soybean meal with increasing amounts of roasted soybean in the diets of crossbred cows to pasture.

Table 6. Lactation performance of animals fed diets containing different forms of soybean.

\begin{tabular}{lrrrrrr}
\hline \multirow{2}{*}{ Variables } & \multicolumn{9}{c}{ Diets $^{1}$} & \multirow{2}{*}{ p-value } & \multirow{2}{*}{ CV(\%) } \\
\cline { 2 - 5 } & SM & \multicolumn{1}{c}{ RaS } & RoS & SMU & & \\
\hline Total milk production (kg) & 29.14 & 26.67 & 26.77 & 27.52 & 0.0541 & 8.19 \\
TMP-3.5\% (kg) & 27.32 & 25.96 & 24.85 & 26.19 & 0.2416 & 10.90 \\
FCM efficiency & 1.28 & 1.26 & 1.21 & 1.22 & 0.6830 & 12.90 \\
MKDM (kg) & 1.48 & 1.40 & 1.41 & 1.39 & 0.3928 & 9.66 \\
MKCP (kg) & 8.60 & 8.33 & 8.30 & 8.17 & 0.6256 & 9.62 \\
\hline & \multicolumn{7}{c}{ Milk composition } & & & \\
\hline Fat (\%) & 3.15 & 3.36 & 3.07 & 3.22 & 0.2201 & 10.30 \\
Protein (\%) & 3.34 & 3.33 & 3.37 & 3.34 & 0.9659 & 5.85 \\
Lactose (\%) & 4.46 & 4.44 & 4.38 & 4.42 & 0.6719 & 3.89 \\
TDE (\%) & 11.89 & 12.12 & 11.78 & 11.88 & 0.2837 & 3.78 \\
\hline
\end{tabular}

${ }^{1} \mathrm{SM}$ (soybean meal); RaS (raw soybean); RoS (roasted soybean); SMU (soybean meal plus 5\% urea); TDE (total dry extract). FCM efficiency ( $\mathrm{kg}$ of milk corrected for $3.5 \%$ fat $/ \mathrm{kg}$ of dry matter consumed). TMP (total milk production), MKDM (milk per kg of dry matter), MKCP (milk per kg of crude protein), Coefficient of variation (CV). Means followed by the same letter in the same row do not differ from each other (Tukey-Kramer test, $5 \%$ probability).

The control diet (soybean meal) and the soybean meal plus urea diet had higher TMP values compared to the raw and roasted soybean diets. These last two diets also had the lowest DM and $\mathrm{CP}$ values, as well as lower milk production/ day (Table 3). Because it is a rich source of metabolizable protein, we expected animals on the roasted soybean diet to produce more milk than those on the raw soybean diet, but this did not happen. In their studies, Oliveira et al. (2007a) and Souza et al. (2009) reported that soybeans ("in natura" or roasted) reduced dry matter intake, but other studies reported increased DMI with soybeans (McNIVEN et al., 2004; GUIDI et al., 2007; MESSANA, 2009).
Higher milk yield can be obtained by adding roasted soybean when the roughage is alfalfa silage, since alfalfa has a higher content of readily soluble protein. Thus, in this study, the roasted soybean would garante a higher amount of metabolizable protein if provided with alfalfa (OLIVEIRA et al., 2007b).

The total milk production corrected to $3.5 \%$ did not differ $(\mathrm{P}>0.05)$ between diets and no difference was detected for feed efficiency ( $\mathrm{P}>0.05)$, as there was no effect on DMI, even for milk corrected for $3.5 \%$ fat.

The control diet had 1.48 more liters of milk per kilogram of dry matter and 8.60 more liters per pound of crude protein, relative to the other diets. 
For each kilogram of DM consumed by animals on the control diet, there were 80,70 and 90 more grams of milk when compared to the raw soybean, roasted soybean and soybean meal with urea diets, respectively. Moreover, each kilogram of $\mathrm{CP}$ obtained from the control diet afforded 270, 300 and 430 grams more milk than the other diets.

Milk composition was also not affected by the diets ( $\mathrm{P}>0.05$; see Melo et al. (2006) and Davidson et al. (2003) for similar results).

The fat concentration in milk was not significant, which may be attributed to the NDF intake, which was similar across diets and sufficient to prevent any reduction in milk fat content (Table 4). Andrade (2011) reported similar findings (but see Mourthé (2011), who observed differences for fat content production). The raw soybean diet had the highest value (3.36\%), and the soybean meal plus urea diet had a mean of 3.22, which was lower than the value of $3.73 \%$ reported by Pina et al. (2006). Perhaps the amount of oil encapsulated in the grains was not sufficient to adversely affect fiber digestibility in our study. López et al. (2007) also observed higher milk fat content in cows that consumed raw soybeans.

Since roasting can protect the soybeans, which would help produce proteins with a more adequate amino acid profile (in turn, producing greater amounts of metabolizable protein for synthesis in the mammary glands), we expected the different diets to affect the protein content in the milk, but we did not observe this. Perhaps the 14-day adaptation period was not sufficient to observe an increase in the amino acid profile.

The mean lactose amounts were not altered by the different diets: $4.46 \%$ (soybean meal), $4.44 \%$ (raw soybeans), $4.38 \%$ (roasted soybean) and $4.42 \%$ (soybean meal with urea). Aquino et al. (2006) reported similar results $(4.63 \%, 4.66 \%$ and $4.64 \%$ with different amounts of urea), and López et al. (2007), using three sources of fat, did not observe any differences in lactose concentration between the treatments tested, yielding values between $4.8 \%$ and $5.0 \%$. According to Andrade (2011), lactose is virtually unaltered by the diet because it is osmotically active (i.e., it is involved in the mobilization of water that promotes osmotic equilibrium between the intracellular and extracellular environments).

The percentage of total dry milk extract (mean of $11.91 \%$ ) also did not differ among diets. This value is considered normal and represents the sum of the behavior of the other milk components.

Finally, the raw and roasted soybean diets had the lowest net revenues ( $\mathrm{R} \$ 1.35$ and $\mathrm{R} \$ 1.12 / \mathrm{cow} /$ day) and the lowest cost per kilogram of milk produced ( $\mathrm{R} \$ 0.25$ and $\mathrm{R} \$ 0.24)$ relative to the control diet, which had a net revenue of $\mathrm{R} \$ 9.33$ and a cost per kilogram of milk produced of $\mathrm{R} \$ 0.22$ (Table 7). The soybean meal with urea diet led to a positive economic outcome, which was closer to that of the control diet (net revenue of $\mathrm{R} \$ 0.58$ / day/cow and an approximate cost per kilogram of milk produced of $\mathrm{R} \$ 0.23$ ). Therefore, the use of soybean meal with urea was more economically viable than the control diet (soybean meal). 
Table 7. Economic viability of the different diets tested.

\begin{tabular}{|c|c|c|c|c|}
\hline \multirow{2}{*}{ Variable $^{2} /(R \$)$} & \multicolumn{4}{|c|}{ Diets $^{1}$} \\
\hline & SM & $\operatorname{RaS}$ & RoS & SMU \\
\hline TFC (kg/day) & 2.22 & 2.23 & 2.23 & 2.20 \\
\hline TCC (kg/day) & 4.47 & 4.45 & 4.28 & 4.18 \\
\hline Cow milk (kg/day) & 29.14 & 26.67 & 26.77 & 27.52 \\
\hline CkgMproduced $^{3}$ & 0.22 & 0.25 & 0.24 & 0.23 \\
\hline Milk recipe $^{4}$ & 16.02 & 14.66 & 14.72 & 15.13 \\
\hline Net revenue 5 & 9.33 & 7.98 & 8.21 & 8.75 \\
\hline
\end{tabular}

${ }^{1} \mathrm{SM}$ (soybean meal); RaS (raw soybean); RoS (roasted soybean); SMU (soybean meal plus 5\% urea); ${ }^{2} \mathrm{TFC}$ (total forage cost); TCC (total concentrate cost); ${ }^{3} \mathrm{CkgMproduced}$ (cost per kilogram of milk produced) obtained by multiplying the dry matter intake by the total cost of each treatment diet, considering the relative cost of each ingredient, ${ }^{4}$ Milk recipe $=$ milk production obtained in each treatment at the amount of $\mathrm{R} \$ 0.55 /$ liter per liter of milk (May/2007). ${ }^{5}$ e Net revenue $=$ milk recipe - cost of the diet. Ingredient prices: corn silage (tons) $=\mathrm{R} \$ 70.00$; soybean meal $(60 \mathrm{~kg})=\mathrm{R} \$ 32.00$; corn meal $(60 \mathrm{~kg})=\mathrm{R} \$ 19.38$; raw soybean $(60$ $\mathrm{kg})=\mathrm{R} \$ 30.15$; toasted soybeans $(60 \mathrm{~kg})=\mathrm{R} \$ 31.00$; urea $(60 \mathrm{~kg})=\mathrm{R} \$ 60.00$; baking soda $(60 \mathrm{~kg})=\mathrm{R} \$ 72.00$; magnesium oxide $(60 \mathrm{~kg})=\mathrm{R} \$ 39.60$; mineral mixture $(60 \mathrm{~kg})=\mathrm{R} \$ 48.00)$. Mineral mixture $=$ Limestone $(1.07 \%)$; dicalcium phosphate $(0.45 \%)$; sodium chloride $(7.8 \%)$; K iodate $(0.0227 \%)$; Na selenite $(0.0106 \%)$; Cu sulfate $(0.5783 \%)$; zinc sulfate $(1.1021 \%)$; sulfur flower (11.37\%); Buffering 2:1 (sodium bicarbonate: magnesium oxide). To calculate the cost of the diets, we took the price of ingredients considering the variation in Brazil in 2007, according to data from Boletim Boi \& Cia, which includes information from the physical and future market inputs based on the dollar index factor.

\section{Conclusion}

Raw and roasted soybeans, as well as concentrate plus $5 \%$ urea in the dry matter, can be used in the diet of high producing cows as an alternative to soybean meal without interfering with milk production and composition. The use of soybean meal plus urea was the most economically viable option.

\section{Acknowledgments}

We thank the Conselho Nacional de Desenvolvimento Científico e Tecnológico/CNPq (National Council for Scientific and Technological Development) for their financial assistance during the research project and the Fundação Cearense de Apoio ao Desenvolvimento Científico e Tecnológico- FUNCAP- CE (Ceará Foundation for the Support of Scientific and Technological development) for the awarded doctoral scholarship.

\section{References}

ANDRADE, V. R. Diferentes processamentos da soja na dieta de vacas F1, em pastagem de capim-braquiária.
2011. Dissertação (Mestrado em Zootecnia) - Faculdade de Ciências Agrárias, Universidade Federal dos Vales do Jequitinhonha e Mucuri, Diamantina.

AQUINO, A. A.; BOTARO, B. G.; IKEDA, F. S.; RODRIGUES, P. H. M.; MARTINS, M. F.; SANTOS, M. V. Efeito de níveis crescentes de uréia na dieta de vacas em lactação, sobre produção e composição físicoquímica do leite. Revista Brasileira de Zootecnia, Viçosa, MG, v. 36, n.4, p. 39-45, 2006.

BARLETTA, R. V.; RENNÓ, F. P.; GANDRA, J. R.; FREITAS JUNIOR, J. É.; VERDURICO, L. C.; MINGOTI, R. D.; VILELA, F. G. Desempenho e parâmetros sanguíneos de vacas leiteiras alimentadas com grão de soja. Archivos de Zootecnia, Córdoba, v. 61, n. 236, p. 483-492, 2012.

BARNABÉ, E. C.; SANTOS, F. A. P.; BITTAR, C. M. M.; PIRES, A. V.; IMAIZUMI, H.; JUCHEM, S. O. Fontes protéicas e energéticas com diferentes degradabilidades ruminais para vacas em lactação. Animal Sciences. Acta Scientiarum, Maringá, v. 29, n. 2, p. 209-216, 2007.

BRODERICK, G. A.; CLAYTON, M. K. A statistical evaluation of animal and nutritional factors influencing concentrations of milk urea nitrogen. Journal of Dairy Science, Madison, v. 80, n. 11, p. 2964-2071, 1997.

CARVALHO, N. M. Utilização do grão tostado de soja (Glycine max. (L) Merril) na alimentação de vacas em lactação. 2001. Tese (Doutorado em Zootecnia) Programa de Pós-Graduação em Agronomia. Faculdade 
de Agronomia. Universidade Federal do Rio Grande do Sul, Porto Alegre.

CASALI, A. O.; DETMANN, E.; VALADARES FILHOI, S. C.; PEREIRA, J. C.; HENRIQUE, L. T.; FREITAS, S. G.; PAULINO, M. F. Influência do tempo de incubação e do tamanho de partículas sobre os teores de compostos indigestíveis em alimentos e fezes bovinas obtidos por procedimentos in situ. Revista Brasileira de Zootecnia, Viçosa, MG, v. 37, n. 2, p. 335-342, 2008.

COMPANHIA NACIONAL DE ABASTECIMENTO CONAB. Acompanhamento de safra brasileira: grãos, sexto levantamento, março 2013. Companhia Nacional de Abastecimento. Brasília: Conab, 2013.

DAVIDSON, S.; HOPKINS, B.; DIAZ, D. E.; BOLT, S. M.; BROWNIE, C.; FELLNER, V.; WHITLOW, L. W. Effects of amounts and degradability of dietary protein on lactation, nitrogen utilization, and excretion in early lactation holstein cows. Journal of Dairy Science, Madison, v. 86, n. 5, p. 168-1689, 2003.

ENJALBERT, F.; MONCOULON, R.; VERNAY, M.; GRIESS, D. Effects of different forms of polyunsaturated fatty acids on rumen fermentation and total nutrient digestibility of sheep fed prairie hay based diets. Small Ruminant Research, Newton, v. 14, n. 2, p. 127-135, 1994.

GUIDI, M. T.; SANTOS, F. A. P.; BITTAR, C. M. M.; PIRES, A. V.; MENEZES JÚNIOR, M. P.; IMAIZUMI, H. Efeito de fontes e teores de proteína sobre digestibilidade de nutrientes e desempenho de vacas em lactação. Acta Scientiarum Animal Science, Maringá, v. 29, n. 3, p. 325331, 2007.

INSTITUTO BRASILEIRO DE GEOGRAFIA E ESTATÍSTICA - IBGE. Indicadores agropecuários. Produção pecuária. Rio de Janeiro: IBGE, 2010. Disponível em: <http://www.ibge.gov.br/>. Acesso em: 21 maio 2012.

ITAVO, L. C. V.; VALADARES FILHO, S. C.; SILVA, F. F.; VALADARES, R. F. D.; PAULINO, M. F.; IVAVO, C. C. B. F.; MORAES, E. H. B. K. Comparação de indicadores e metodologia de coleta para estimativas de produção fecal e fluxo de digesta em bovinos. Revista Brasileira de Zootecnia, Viçosa, MG, v. 31, n. 4, p. 1833 1839, 2002.

LOPES, M. A.; ALMEIDAJÚNIOR, G. A.; CARVALHO, F. M. Rentabilidade de um sistema de produção de leite tipo B: Um estudo de caso com a raça Jersey, no Estado de São Paulo. Revista Economia Rural, São Paulo, v. 2, n. 2, p. 215-221, 2003.
LÓPEZ, S.; LÓPEZ, J.; STUMPF JUNIOR, W. Produção e composição do leite e eficiência alimentar de vacas da raça Jersey suplementadas com fontes lipídicas. Archivos Latinoamericanos de Producción Animal, Córdoba, v. 15, n. 1, p. 1-9, 2007.

MCNIVEN, M. A.; DUYNISVELD, J.; CHARMLEY, E.; MITCHELL, A. Processing of soybean affects meat fatty acid composition and lipid peroxidation in beef cattle. Animal Feed Science and Technology, Amsterdam, v. 116, n. 1, p. 175-184, 2004.

MELO, A. A. S.; FERREIRA, M. A.; VÉRAS, A. S. C.; LIRA, M. A.; LIMA, L. E.; PESSOA, R. A. S.; BISPO, S. V.; CABRAL, A. M. D.; AZEVEDO, M. Desempenho leiteiro de vacas alimentadas com caroço de algodão em dieta à base de palma forrageira. Pesquisa Agropecuária Brasileira, Brasília, v. 41, n. 7, p. 1165-1171, 2006.

MESSANA, J. D. Teores de lipídios em dietas de novilhos nelore sobre parâmetros ruminais, desempenho e características de carcaça. 2009. Tese (Doutorado em Ciência Animal) - Universidade Estadual Paulista, Jaboticabal.

MOREIRA, A. L.; ODILON, G. P.; GARCIA, R.; VALADARES FILHO, S. C.; CAMPOS, M. S.; MORAES, S. A.; ZERVOUDAKIS, J. T. Consumo e digestibilidade aparente dos nutrientes da silagem de milho e dos fenos de alfafa e de Capim-Coastcross, em ovinos. Revista Brasileira de Zootecnia, Viçosa, MG, v. 30, n. 3, p. 1099-1105, 2001. Suplemento 1.

MOURTHÉ, M. H. F. Grãos de soja tostado como suplemento para vacas Holandês $x$ Gir em pastagem de Brachiaria brizantha cv. 2011. Tese. (Doutorado em Zootecnia) - Escola de Veterinária, Universidade Federal de Minas Gerais, Marandu.

NATIONAL RESEARCH COUNCIL - NRC. Nutrient requirements of dairy cattle. $7^{\text {th }}$ ed. Washington: National Academy Press, 2001. 408 p.

OLIVEIRA, A. S.; CAMPOS, J. M. S.; LANA, R. P. Uso do conceito de análise marginal para estimar o nível ótimo de suplementação com alimentos concentrados para vacas de leite em pastagens. In: LANA, R. P. (Ed.). Respostas biológicas aos nutrientes. Viçosa, MG: Editora CPD, 2007a. p. 155-177.

OLIVEIRA, A. S.; CAMPOS, J. M. S.; VALADARES FILHO, S. C.; ASSIS, A. J.; TEIXEIRA, R. M. A.; VALADARES, R. F. D.; PINA, D. S.; OLIVEIRA, G. S. Substituição do milho por casca de café ou de soja em dietas para vacas leiteiras: consumo, digestibilidade dos nutrientes, produção e composição do leite. Revista Brasileira de Zootecnia, Viçosa, MG, v. 36, n. 4, p. 11721182, 2007b. Suplemento. 
OLIVEIRA, L. O. F.; SALIBA, E. O. S.; RODRIGUEZ, N. M.; GONÇALVES, L. C.; BORGES, I.; AMARAL, T. B. Consumo e digestibilidade de novilhos Nelore sob pastagem suplementados com misturas múltiplas. Arquivo Brasileiro de Medicina Veterinária e Zootecnia, Belo Horizonte, v.56, p. 61-68, 2004.

PINA, D. S.; VALADARES FILHO, S. C.; DINIZ, R. F.; CAMPOS, J. M. S.; DETMANN, E.; MARCONDES, M. I.; OLIVEIRA, A. S.; TEIXEIRA, R. M. A. Consumo e digestibilidade aparente total dos nutrientes, produção e composição do leite de vacas alimentadas com dietas contendo diferentes fontes de proteína. Revista Brasileira de Zootecnia, Viçosa, MG, v. 35, n. 4, p. 1543-1551, 2006.

SANTOS, F. L.; LANA, R. P.; SILVA, M. T. C.; BRANDÃO, S. C. C.; VARGAS, L. H. Produção e Composição do leite de vacas submetidas a dietas contendo diferentes níveis e formas de suplementação de lipídios. Revista Brasileira de Zootecnia. Viçosa, MG, v. 30, n. 4, p. 1376-1380, 2001.
SILVA, D. J.; QUEIROZ, A. C. Análise de alimentos: métodos químicos e biológicos. 3. ed. Viçosa: UFV. 2002. $235 \mathrm{p}$.

SKLAN, D.; ASHKENAZI, R.; BRAUN, A.; DEVORIN, A.; TABORI, K. Fatty acids, calcium soaps of fatty acids, and cottonseeds fed to high yielding caws. Journal of Dairy Science, Madison, v. 75, n. 9, p. 2463-2472, 1992.

SOUZA, A. R. D. L.; MEDEIROS, S. R.; MORAIS, M. G.; OSHIRO, M. M.; TORRES JUNIOR, R. A. A. Dieta com alto teor de gordura e desempenho de tourinhos de grupos genéticos diferentes em confinamento. Pesquisa Agropecuária Brasileira, Brasília, v. 44, n. 7, p. 746-753, 2009.

STATISTICAL ANALYSIS SYSTEM INSTITUTE SAS INSTITUTE. Sas user's guide: statistics, versão 5. Cary: Statistical Analysis System Institute, 1999. 1028 p. 